\title{
COGNITIVE AND DISCOURSE TACTICS OF SPORTS EVENT REPRESENTATION IN THE NEWS TEXT: DIACHRONICH APPROACH ${ }^{1}$
}

\author{
Olga S. Volkova \\ Volgograd State University, Volgograd, Russian Federation
}

\begin{abstract}
The paper is devoted to the comparison of linguistic means of sports event description in two English news text corpora, belonging to different historical periods. It is aimed at revealing the peculiarities of implementing such cognitive and discursive tactics as accuracy, reliability, heroisation and glorification in representation of a socially significant event in British media discourse. News reports on sporting events at the Olympic Games held in London in 1908 and 1948 were chosen as the object of the study. The research is focused on linguistic techniques of nominating sports events, the central constituent of which is the participants - athletes.

Different means of informing, containing personal data descriptors, such as proper noun, age, profession, sports results, were identified in the process of text analysis. The use of sportsman and sports event heroisation and glorification tactics is traced back to 1908. By 1948 they became the linguistic characteristics of an English sports report. The tactics of the athlete glorification enables the formation of a socially significant person image. It is represented in enthusiastic descriptions of such forms of sports events as the Opening and Awards Ceremonies, competitions. The novelty of the results achieved is accounted for the use of historical and discursive analysis technique, which considers the peculiarities of sports event representation, as well as its major constituent - the athlete - in the media. The analysis of text corpora, belonging to different historical periods, helped to reveal the dynamics of sports event representation tactics.
\end{abstract}

Key words: media discourse, tactics, event, news item, representation.

УДК 811.111:070.431

Дата поступления статьи: 03.10.2016

ББК $81.432 .1-51$

Дата принятия статьи: 07.11.2016

\section{КОГНИТИВНО-ДИСКУРСИВНЫЕ ТАКТИКИ РЕПРЕЗЕНТАЦИИ СПОРТИВНОГО СОБЫТИЯ В НОВОСТНОМ ТЕКСТЕ: ДИАХРОНИЧЕСКИЙ АСПЕКТ ${ }^{1}$}

\author{
Ольга Сергеевна Волкова \\ Волгоградский государственный университет, г. Волгоград, Российская Федерация
}

\begin{abstract}
Аннотация. Статья посвящена сравнению вербальных средств описания спортивного события в двух относимых к разным историческим периодам англоязычных миникорпусах новостных текстов. Ее цель выявить особенности реализации когнитивно-дискурсивных тактик точности, достоверности, героизации и глорификации при репрезентации спортивного события в британском медиадискурсе. Объектом исследования были выбраны новостные сообщения об Олимпиадах, проходивших в Лондоне в 1908 и 1948 гг., предметом стали языковые приемы номинации и описания спортивных событий, центральным конституентом которых являются их участники - спортсмены. Анализ позволил установить приемы информирования, осуществляемого посредством дескрипторов личных данных (имя собственное, возраст, профессия, спортивные результаты), реализующих в новостном сообщении тактики точности и достоверности, а также отметить ஜํำ зачатки формирования тактик героизации и глорификации спортсмена и спортивного события в 1908 г., (2) которые к 1948 г. стали лингвостилистической характеристикой англоязычного спортивного репортажа. Ге-
\end{abstract}




\section{МАТЕРИАЛЫ И СООБЩЕНИЯ}

роизации спортсмена способствовало именование текущего или уже имеющегося спортивного достижения, описание церемонии вручения награды, глорификация в репортажах 1948 г. осуществлялась посредством описания восторженного отношения зрителей к спортсмену. Тактика глорификации спортивного события нацелена на повышение его социальной привлекательности, что выражается в возвышенно-восторженной тональности описания таких форм спортивного события, как открытие олимпиады, соревнование, награждение победителей. Новизна полученных результатов объясняется применением историко-дискурсивных методик анализа, позволивших рассмотреть особенности медиарепрезентации спортивного события и его главного конституента - спортсмена - на синхронных срезах корпусов текстов, относящихся к разным историческим периодам, и, сравнив полученные данные, выявить динамику тактик изображения спортивного события в аспекте диахронии.

Ключевые слова: медиадискурс, тактика, событие, новостное сообщение, репрезентация.

\section{1. Методология исследования}

Вопрос о специфике медиарепрезентации текущих событий сегодня активно обсуждается в лингвистике. Следуя теоретическим положениям специалистов по медиалингвистике, указывающих на множественные связи медийных текстов с социокультурными условиями их порождения и прочтения (например: $[1 ; 4 ; 5 ; 7 ; 14 ; 20 ; 29 ; 30-32$ и др.]), исследователи подробно анализируют отдельные категории медиадискурса [11; 16; 19 и др.], его жанровую и стилевую стратификацию [2; 6; 26 и др.], выводят в фокус научного интереса отдельные аспекты лингвистического представления новостей в информационном поле [8; 10 ; $15 ; 23 ; 28$ и др.]. Наряду с социокультурным и жанрово-стилевым подходами медийный дискурс изучается и с позиций когнитивно-дискурсивного моделирования: анализируются особенности репрезентации образов и имиджей социально значимых личностей в русскои англоязычном медийных дискурсах [3], выявляются особенности информативности медийного макродискурса, ролевой структуры события [12;13], устанавливается специфика презентации событий в тексте новостного сообщения [23; 24; 27$]$.

Исследователи пришли к общему мнению о том, что сегодня производство новостей - это индустрия, создающая медийный продукт с целью привлечения внимания как можно большего числа людей к социально значимой информации. Называя этот процесс индустрией, ученые подчеркивают, что, вопервых, количество событий, происходящих в мире, практически неограниченно, информационный поток движется вслед за временем, мотивируя производство медиатекстов; во- вторых, медийной индустрии общество доверило право формировать ленту новостей, иными словами, из информационного поля дня журналисты структурируют медийную картину мира с учетом разных групп интенций потребностей в достоверной и правдивой информации, социальном единении и управлении, а также в коммерциализации медийного продукта $[9 ; 15 ; 17 ; 18]$, что отражается в выборе фактов, стратегий, тактик, форм и приемов их репрезентации, стилистике словесного описания $[23 ; 25 ; 27 ; 31]$.

При когнитивно-дискурсивном моделировании новостного сообщения в медийной лингвистике принято опираться на представление об универсальной когнитивной схеме моделирования фрейма события, в который включаются такие обязательные кластеры, как участник события, действия и / или состояния, временные и пространственные рамки события [31]. Этот процесс именуется в работах по когнитивной лингвистике «репрезентацией» референта [22, с. 14]. Анализ приемов репрезентации социальной действительности в медиадискурсе на основе значительного корпуса новостных текстов позволил исследователям прийти к объективно обоснованному заключению о наличии медиарепрезентации как специфичной для информационно-новостного дискурса процедуре конструирования события. В журналистской практике существует мнение о том, что в мире ежесекундно происходят события и формируются факты, однако не все из них становятся новостью - социально значимым фактом, имеющим последствия, событием, выбивающимся из обычного хода вещей и тем самым привлекающим внимание общества. Данная особенность новостного сообщения в англоязычной медиа- 
лингвистике весьма точно и метафорично обозначена двумя терминами: news value (having a certain value, being news worth) и click bait (an eye-catching link on a website which encourages people to read on). Специфика медиарепрезентации события проявляется не только в качестве истории о факте, происшествии, составляющей основу содержания текста. Новость, несомненно, сообщает о действиях участников, изменениях в мире, но также указывает на причины и возможные последствия доминирующего события, вокруг которого формируется содержание новостного текста. Именно причины и последствия события оказываются значимыми, и об этом новостной текст тоже информирует.

Проводимые сегодня исследования убеждают в наличии стратегий и тактик медиатизации события, которые реализуются приемами его репрезентации по типам «отражение» или «конструирование» [25; 27], а также в том, что точность, достоверность, фокусность информирования являются когнитивно-дискурсивными тактиками медиарепрезентации новостного события [17; 23]. Различия в коммуникативных тактиках и дискурсивнотекстовых приемах репрезентации события в новостном тексте объявляются обусловенными социокультурными и прагматическими мотивами.

В нашем исследовании указанные выше положения получили развитие в историко-дискурсивном аспекте. Изучение особенностей медиарепрезентации события проводилось на материале корпуса спортивных новостей, размещенных в архиве британских газет ${ }^{2}$. Для анализа было отобрано 500 англоязычных текстов новостей, посвященных спортивным мероприятиям (соревнованиям, ритуалам награждения победителей и др.) на Олимпийских играх, проходивших в Великобритании в 1908, 1948 годах. Применяя принятые в исторической дискурсологии методику сравнительного анализа группы однородных текстов, относимых к единому историческому периоду, и методику сопоставления лингвистических реализаций общих дискурсивных и текстовых категорий в текстах, относимых к разным периодам [21], а также избрав в качестве смысловой доминанты положение медиалингвистики о ког- нитивно-дискурсивном моделировании события $[17 ; 18 ; 25 ; 32$ и др.], мы провели анализ использованных в новостных сообщениях номинаций участников спортивных событий, установили приемы их репрезентации в миникорпусах текстов за указанные временные периоды с целью выявить историческую динамику в тактиках медиарепрезентации спортсмена и спортивного события.

\section{2. Тактики медиарепрезентации спортсмена}

В миникорпусе новостей об Олимпийских играх, проходивших в 1908 г., содержатся лаконично составленные отчеты о результатах спортивных соревнований. В них называются участники, вид спорта, этап соревнования, перечисляются победители, например: Miss Eastlake Smith beat Miss Greene in Ladies' Final, thus winning' Olympic Gold Medal. Bronze Medal winner, Mrs. Adlerstrahle (YTS 11/05/1908 "Olympic Lawn Tennis”), то есть используется прием точного воспроизведения личных данных. Как следует из приведенного примера, дескрипторами являются имена собственные и маркеры социального статуса спортсмена, эти единицы заполняют субъектно-объектные позиции активных предикатов beat, win. Наряду с личными данными в текстах наличествуют дескрипторы-топонимы, указывающие на страну, за которую выступает спортсмен: In the gentlemen's event it will probably be found that Ulrich Salchow, of Sweden, showed the best form. N. Panin of Russia, was also a prominent competitor (MC 29/10/1908 "Olympic Skating. Figure Competitions"). В приведенном фрагменте следует отметить наличие комментария репортера в части оценки спортивной формы участников (the best form, a prominent competitor) как основания для прогноза исхода соревнования (it will probably be found). В следующем примере, информирующем о победах в женском катании на коньках, наряду с упоминанием превосходной формы спортсменок и позитивным описанием их физического состояния автор вводит дескриптор, указывающий на уже имеющиеся спортивные достижения: In the ladies event, Mrs. Syers, United Kingdom, the champion, showed the 


\section{МАТЕРИАЛЫ И СООБЩЕНИЯ}

best form, Mrs. Greenbough, United Kingdom, also showed good form (MC 29/10/1908 "Olympic Skating. Figure Competitions"). Перечисление уже имеющихся спортивных титулов (champion, title-holder) в текстах 1908 г. сопровождает репрезентацию только британских спортсменов, что связано с региональным принципом информирования [31] - читатель британской газеты в 1908 г. был слабо осведомлен о спортивных достижениях в других странах мира.

Отметим, что редкое включение в стандартный порядок представления участников или победителей соревнования дескрипторов «имеющиеся личные спортивные достижения» (например, champion), «оценка физического состояния спортсмена» (good form, the best form) отражает начальный этап формирования тактики героизации при репрезентации участников спортивных событий.

В новостных сообщениях о событиях Олимпийских игр 1948 г. спортсмены остаются центральными фигурами. При их назывании, как и в текстах 1908 г., используется прием точного воспроизведения личных данных (имени, отчества, возраста, страны): John Parlett, twenty-three-year-old Working art student, has a great chance to win the 800 metres final to-day (AJ 02/08/1948 "Britain's Olympic Track Hopes Rise”). При этом репортер часто указывает на профессию атлета, подчеркивая соблюдение им одного из главных принципов Олимпийских игр - к участию в них допускаются только спортсмены-любители. Определение участника игр было сформулировано в 1905 г. на Международном олимпийском конгрессе в Брюсселе: «An amateur is any person who has never taken part in race or meeting or competition open to all comers, for a prize in money or for a gate money, or with professionals, and who has not been during his lifetime a professional or hired teacher of physical exercises» (The Fourth Olympiad: Official report, London, 1908). Анализ миникорпуса текстов за 1948 г. показал разнообразие профессий спортсменов-любителей. Это студенты, инженеры, полицейские, военные, моряки. Стилистическую специфику медиарепрезентации спортсмена можно охарактеризовать как лаконичность, точность, достоверность информирования в сочетании со знаками героизации. Они полу- чают выражение в субстантивированной предикативной структуре предложения, усложненной перечислением значимых дескрипторов спортсмена «название вида спорта» и «этап спортивного соревнования»: A military policeman, Donald Scott, British light heavyweight champion, and Sailor Johnny Wright, the middleweight title-holder, are in the Olympic boxing finals (AJ 13/08/1948 "Two Britons in Boxing Finals"). В следующем примере точность и достоверность при характеристике спортивных побед реализуются в сложных предикативных моделях предложений, дополняются дескриптором «измерение спортивных достижений (результатов)»: The record of 52 sec. for the 400 metres hurdles set up G. Hardin (U.S.A.), at Los Angeles in 1932, was twice broken within a few minutes first by the Swede, R. Larsson, who clocked $51.9 \mathrm{sec}$. in winning his semi-final heat, and then Roy Cochran, the American, who won the second semi-final in the same time. Britain's sole representative, Harry Whittle, the former Army captain, was eliminated in Cochran's heat, taking only fourth position (WMN 31/ 07/1948(6)).

Усилению героизации способствует включаемое в тексты сообщения описание ритуалов награждения (появление пьедестала почета, исполнение гимна страны, спортсмен которой занял первое место): The first victor the Games was Madamoiselle Ostermeyer, of France, who won the women's throwing the discus event. She stood, smiling and triumphant, on the platform labelled with the figure one, while the second and third competitors stood below her on the other platforms. The band played the Marseillaise and everyone in the great assembly stood to attention (WMN 31/07/1948(3)).

В корпусе 1948 г. информативно значимые дескрипторы, характеризующие спортсмена, дополняются привлекательными фактами и событиями из его личной жизни, что свидетельствует о реализации тактики глорификации. Так, текст «Olympic Visitor» начинается с сообщения о родственных связях с Шотландией олимпийского чемпиона из США: Spending a few days' holiday in Dundee is an American Olympic runner, 27-year-old Edward O'Toole, of Brooklyn, New York. He 
is staying with family friends, Mrs Smith and Miss Anne Smith, 23 Scott Street, who were in New York visiting relatives last year. $\mathrm{Mr}$ O'Toole's mother was a Miss Helen Beaton, who lived in Cooper Street, Lochee. He is disappointed that time has not permitted a visit to his father's native heath in Galway <...> During his stay Dundee he has visited Braemar and the Perthshire Highlands and wishes he had had the opportunity for ordering some Scottish tweeds (DET 11/08/1948). Из следующего абзаца читатель получает точные и достоверные сведения о предстоящем соревновании, в котором примет участие чемпион: $M r O$ 'Toole ran in the 10.000-metre race, being placed seventh. To-morrow he will be running at the White City Stadium for an American team against British Empire team in the three-mile race. Предикативные части данных предложений передают значимую информацию о спортивном событии, однако далее автор возвращается к тактикам героизации и глорификации спортсмена: For the last three years he has been national champion in the 10,000 metres. His other main interest in sports is tennis $<\ldots>$ In order to keep in trim for his race to-morrow. Mr O'Toole has done some sprinting in Lochee Park, where youngsters have been quick to obtain Olympic runner's autograph (DET 11/08/1948).

\section{3. Тактики медиарепрезентации спортивного события}

Наряду с тактиками героизации и глорификации спортсмена в изученных миникорпусах текстов - репортажей о спортивных событиях Олимпийских игр в 1908 г. - отмечается глорификация спортивных событий, которая проявляется не только в восхвалении спортивной формы или достижений спортсмена, но и в создании позитивного имиджа соревнований международного уровня, о чем мечтал вместе с другими организаторами современного олимпийского движения Пьер дэ Кубертен (organized sport can create moral and social strength) и что представлено в клятве олимпийца: We swear that we will take part in the Olympic Games in loyal competition, respecting the regulation which govern them, and desirous of participating in them in the true spirit sportsmanships for the honour of our country and for the glory of sport (Olympic Oath, https:/ /en.wikipedia.org/wiki/Olympic_Oath).

В некоторых заметках о социальных мероприятиях, проводимых организаторами Олимпийских игр в 1908 г., приводятся непрямые цитации выступлений, посвященных чествованию команд-участниц: Speaking at a luncheon given by the Phyllis Court Club to the competitors at the Olympic Regatta at Henley, yesterday, Lord Desborough said, that though Italy was unable to organise this year's Olympic Games they had achieved their full share of success. Though Dorando did not win the Marathon race he certainly carried off most of the honours. His Lordship referred to the friendship cemented through the meeting of various athletic representatives, and said no peace conference could ever rival the spontaneous enthusiasm of athletes when they drank the health of one another. If by the prowess foreign crews deserved to win their victory would be received with enthusiasm by the English people (MC 28/07/1908 (9) "Atheletes as Peacemakers"). Как следует из приведенного примера, в начале прошлого века организаторы игр стремились точно следовать основной цели возрождаемого олимпийского движения - посредством международных спортивных соревнований способствовать формированию философии мирного существования народов. Обилие в тексте абстрактных имен существительных с положительной социальной коннотацией способствует созданию возвышенно-восторженной тональности сообщения. В миникорпусе текстов об Олимпийских играх 1948 г. указанная тактика сохраняется, в частности, в заметках об отдельных спортсменах, ставших известными благодаря своим победам и рекордам, приводятся их комментарии о желании встретиться с членами команд из разных стран мира: He has enjoyed meeting runners of many nationalities at the Games and is sorry the scattered camps made it impossible to meet a greater number (DET 11/08/1948).

В корпусе за 1948 г. представлены репортажи о ритуалах, в частности о церемонии доставки олимпийского огня и открытии спортивных соревнований. Если в 1908 г. открытие Олимпиады состояло в кратком 


\section{МАТЕРИАЛЫ И СООБЩЕНИЯ}

объявлении короля Георга VI и парадном выходе всех команд-участниц, то в 1948 г. ее открытию предшествовала эстафета олимпийского факела, а церемония открытия сопровождалась театрализованным представлением, посвященным истории игр: It was as if some Spartan youth had, by a miracle of transmigration, been suddenly sent by the gods of Olympus to visit the Stadium. He was a tall figure, snow-white in vest and shorts showing against the sun-bronze of his limbs. In his right hand he bore aloft a torch which flared with the brilliance of magnesium. This was the big moment for the 82,000 who had seen the King declare open the fourteenth Olympiad of the modern era. Though it was not one nation's show, but a display of panoramic splendour to which the men and women of fifty-nine lands contributed, it was a young Briton who struck the most triumphant note (AJ 25/08/1948 "Olympic Athletes in Action"). В приведенном новостном фрагменте исторические факты объединены с описанием реальных событий на стадионе, общая тональность текста возвышенно-торжественная.

\section{4. Выводы}

Результаты сравнительного изучения когнитивно-дискурсивных тактик представления спортивного события и спортсмена как его центрального конституента в миникорпусах текстов об Олимпийских играх в Лондоне в 1908 и 1948 гг. убеждают в перспективности историко-дискурсивного подхода к выявлению приемов прямой номинации и репортажному описанию спортивных событий в новостном сообщении. Он позволил установить типизированный состав дескрипторов номинации спортсмена, языковые средства выражения тактик точности и достоверности при репрезентации спортивных соревнований, что способствует реализации основной коммуникативной цели новостного сообщения - информированию о социально значимом событии. Кроме того, в результате применения историко-дискурсивного подхода к анализу медиатекстов показаны приемы формирования тактик героизации и глорификации спортивного события и спортсмена, способствующих повышению привлекательности текста для чита- теля. Дальнейший сравнительно-сопоставительный анализ приемов медиарепрезентации спортивных событий в новостном архиве англоязычных изданий позволит расширить представления о вариативности приемов его изображения, выявить различия в средствах реализации коммуникативной тональности новостного текста.

\section{ПРИМЕЧАНИЯ}

${ }^{1}$ Исследование выполнено при поддержке Российского гуманитарного научного фонда (грант РГНФ № 15-04-00134 «Историческая дискурсология: проблемы, методология и перспективы»).

2 Здесь и далее приводятся примеры из Тhe British NEWSPAPER Archive. URL: http:// britishnewspaperarchive.co.uk/. Каждый пример сопровождается указанием на издание, год и дату его выпуска (см.: Источники).

\section{СПИСОК ЛИТЕРАТУРЫ}

1. Александрова, О. В. Язык средств массовой информации как часть коллективного пространства общества / О. В. Александрова // Язык СМИ как объект междисциплинарного исследования / под ред. М. Н. Володиной. - М. : Изд-во МГУ, 2003. - C. 89-99.

2. Алещанова, И. В. Газетный текст как разновидность массово-информационного дискурса / И. В. Алещанова // Языковая личность: институциональный и персональный дискурс : сб. науч. тр. / под ред. В. И. Карасика, Г. Г. Слышкина. - Волгоград : Перемена, 2000. - С. 131-140.

3. Андрющенко, Е. А. Лингвопрагматический потенциал языковых средств репрезентации образа «чужого» в медиадискурсе Великобритании / Е. А. Андрющенко // Вестник Волгоградского государственного университета. Серия 2 , Языкознание. - 2012. - № 2 (16). - C. 199-204. - DOI: http:// dx.doi.org/10.15688/jvolsu2.2012.2.38.

4. Анненкова, И. В. Медиадискурс XXI века. Лингвофилософский аспект языка СМИ / И. В. Анненкова. - М. : Изд-во Моск. ун-та ; Фак. журналистики МГУ им. М.В. Ломоносова, 2011. - 392 с.

5. Бодрийар, Ж. Реквием по масс-медиа / Ж. Бодрийар // Поэтика и политика. Альманах Российско-французского центра социологии и философии Института социологии Российской Академии Наук. - М. ; СПб. : Ин-т эксперимент. социологии : Алетейя, 1999. - С. 193-226.

6. Болотнов, А. В. Информационное поле медийной языковой личности и ее идиостиль 
/ А. В. Болотнов // Медиалингвистика. - 2015. № 4 (10). - C. 51-59.

7. Борботько, В. Г. Принципы формирования дискурса. От психолингвистики к лингвосинергетике / В. Г. Борботько. - 4-е изд. - М. : Либроком, 2011. $-288 \mathrm{c}$.

8. Борытко, А. Н. К вопросу о терминологической ясности речи спортивного комментатора: экспериментальное исследование / А. Н. Борытко // Известия Волгоградского государственного педагогического университета. Серия «Филологические науки». - 2012. - № 8 (72). - С. 19-23.

9. Буряковская, В. А. Коммуникативные характеристики массовой культуры в медийном дискурсе (на материале русского и английского языков) / В. А. Буряковская. - Волгоград : Перемена, 2015. $-228 \mathrm{c}$.

10. Вирен, Г. В. Информационные агентства и информационные сайты Интернета: сравнительный контент-анализ и перспективные тенденции / Г. В. Вирен // Вестник МГУ. Серия 10, Журналистика. - 2009. - Вып. 3. - С. 74-90.

11. Гришаева, Л. И. Как в медиадискурсе информирование становится манипулированием? / Л. И. Гришаева // Вестник Московского государственного лингвистического университета. Языкознание и литературоведение. - 2015. - Вып. 6 (717) : Дискурс как социальная деятельность: приоритеты и перспективы. - С. 179-190.

12. Гробицкая, А. М. К вопросу о тематической стратификации событийного газетного дискурca / А. М. Гробицкая // Вестник Орловского государственного университета. Серия «Новые гуманитарные исследования». - 2012. - № 7 (27). - С. 324-329.

13. Доброва, В. В. Виды событий и их ролевая структура / В. В. Доброва, О. А. Подлесова // Филологические науки. Вопросы теории и практики. 2015. - № 8 (50), ч. III. - С. 76-80.

14. Добросклонская, Т. Г. Вопросы изучения медиатекстов: опыт исследования современной английской медиаречи / Т. Г. Добросклонская. - 3-е изд. М. : КРАСАНД, 2010. -288 c.

15. Евдокимов, В. А. Инфотейнмент в масс-медиа: панацея от скуки и эрзац дискуссии / В. А. Евдокимов // Наука о человеке: гуманитарные исследования. -2010. - № 5. - С. 214-220.

16. Желтухина, М. Р. Медиатексты в современной массовой коммуникации / М. Р. Желтухина // Вестник Центра международного образования Московского государственного университета. Филология. Культурология. Педагогика. Методика. 2013. - № 3. - C. 7-11.

17. Ильинова, Е. Ю. К вопросу о конструировании новостного сообщения / Е. Ю. Ильинова // Вестник Волгоградского государственного университета. Серия 2, Языкознание. - 2015. - № 4 (28). -
C. 96-102. - DOI: http://dx.doi.org/10.15688/jvolsu2. 2015.4.11.

18. Ильинова, Е. Ю. Когнитивно-дискурсивный аспект медиарепрезентации события // Вестник Московского государственного лингвистического университета. Серия «Языкознание». - 2016. Вып. 7 (746) : События в коммуникации и когниции. -С. 87-95.

19. Ионова, С. В. Специфика временных маркеров события в текстах PR-документа и журналистской публикации / С. В. Ионова, А. С. Матвеева // Вестник Волгоградского государственного университета. Серия 2, Языкознание. - 2013. - № 2 (18). - С. 34 40. - DOI: http://dx.doi.org/10.15688/jvolsu2.2013.2.5.

20. Клушина, Н. И. Интенциональная конфигурация медийного пространства / Н. И. Клушина // Политическая лингвистика. - 2013. - № 2 (44). C. $40-46$.

21. Кочетова, Л. А. Историческая дискурсология как вектор развития теории дискурса / Л. А. Кочетова // Вестник Московского государственного лингвистического университета. Серия «Языкознание и литературоведение». - 2015. - Вып. 6 (717) : Дискурс как социальная деятельность: приоритеты и перспективы. - С. 323-334.

22. Кубрякова, Е. С. Язык и знание: На пути получения знания о языке: части речи с когнитивной точки зрения. Роль языка в познании мира / Е. С. Кубрякова. - М. : Языки славянской культуры, 2004. -560 с.

23. Мельникова, Е. А. Специфика медиарепрезентации реальности в жанре новостной заметки / Е. А. Мельникова // Вестник Волгоградского государственного университета. Серия 2, Языкознание. - 2015. - № 4 (28). - C. 103-107. - DOI: http://dx. doi.org/10.15688/jvolsu2.2015.4.12.

24. Основы лингвистического мониторинга медиапространства региона / В. А. Брылева, О. С. Волкова, С. В. Ионова [и др.]. - Волгоград : Волгогр. науч. изд-во, 2011. $-147 \mathrm{c}$.

25. Плотникова, С. Н. Дискурсивное конструирование как теоретическое понятие / С. Н. Плотникова // Известия Волгоградского государственного педагогического университета. Серия «Филологические науки». - 2014. - № 5 (90). - С. 41-46.

26. Тырыгина, В. А. Жанровая стратификация масс-медийного дискурса / В. А. Тырыгина. - М. : Либроком, 2010. - 320 с.

27. Федосеева, Е. В. Типы репрезентации действительности в медиадискурсе (на материале статей о России в британских и американских СМИ) / Е. В. Федосеева // Вестник Иркутского государственного лингвистического университета. Серия «Филология». - 2014. - № 2. - С. 310-316.

28. Bell,A. The Language of News Media /A. Bell. Oxford: Blackwell, 1991.-227 p. 
29. Dominick, J. R. The Dynamics of Mass Communication / J. R. Dominick. - New York : McGrawHill, 1993. $-315 \mathrm{p}$.

30. Elridge, J. The Mass Media Power in Modern Britain / J. Elridge, J. Kitzinger, K. Williams. - Oxford : Oxford University Press, 1997. - 200 p.

31. Hodkinson, P. Media, culture and society: an introduction / P. Hodkinson. - London : SAGE Publications Ltd, 2013. -336 p.

32. Ilyinova, E. Yu. Focal points on constructing news stories / E. Yu. Ilyinova, O. S. Volkova // Вестник Волгоградского государственного университета. Серия 2, Языкознание. - 2015. - № 4 (28). - С. 96102. -DOI: http://dx.doi.org/10.15688/jvolsu2.2015.4.11.

\section{ИСТОЧНИКИ}

$A J$-Aberdeen Journal. - Electronic data. - Mode of access: http://britishnewspaperarchive.co.uk/. - Title from screen.

DET - Dundee Evening Telegraph. - Electronic data. - Mode of access: http://britishnewspaperarchive. co.uk/.- Title from screen.

$M C$ - The Manchester Courier. - Electronic data. - Mode of access: http://britishnewspaper archive.co.uk/. - Title from screen.

$W M N$ - Western Morning News. - Electronic data. - Mode of access: http://britishnewspaper archive.co.uk/. - Title from screen.

YTS - Yorkshire Telegraph and Star (Sheffield Evening Telegraph). - Electronic data. - Mode of access: http://britishnewspaperarchive.co.uk/. - Title from screen.

\section{REFERENCES}

1. Aleksandrova O.V. Yazyk sredstv massovoy informatsii kak chast kollektivnogo prostranstva obshchestva [The Language of Mass Media as a part of collectively shared space of the society]. Yazyk SMI kak obyekt mezhdistsiplinarnogo issledovaniya [Mass Media Language as an Object of Crossdisciplinary Study]. Volodina M.N., ed. Moscow, Izdvo MGU, 2003, pp. 89-99.

2. Aleshchanova I.V. Gazetnyy tekst kak raznovidnost massovo-informatsionnogo diskursa [Newspaper Text as a Type of Mass Media Discourse]. Karasik V.I., Slyshkin G.G., eds. Yazykovaya lichnost: institutsionalnyy $i$ personalnyy diskurs: $c b$. nauch. tr. [Linguistic personality: Institutional and Personal Discourse. Collection of scientific papers]. Volgograd, Peremena Publ., 2000, pp. 131-140.

3. Andryushchenko E.A. Lingvopragmaticheskiy potentsial yazykovykh sredstv reprezentatsii obraza «chuzhogo» v mediadiskurse Velikobritanii
[Lingvopragmatic potential of representation means of "alien" image in the UK media discourse]. Vestnik Volgogradskogo gosudarstvennogo universiteta. Seriya 2, Yazykoznanie [Science Journal of Volgograd State University. Linguistics], 2012, no. 2(16), pp. 199-204. DOI: http://dx.doi.org/10.15688/jvolsu2.2012.2.38.

4. Annenkova I.V. Mediadiskurs XXI veka. Lingvofilosofskiy aspekt yazyka SMI [Media Discourse of the XXI century. Linguistic and philosophical aspect of the Media Language]. Moscow, Izd-vo Moskovskogo universiteta, Fakul'tet zhurnalistiki MGU imeni M.V. Lomonosova, 2011.392 p.

5. Bodriyar Zh. Rekviem po mass-media [Requiem for the media]. Poetika i politika. Almanakh Rossiysko-frantsuzskogo tsentra sotsiologii i filosofii Instituta sotsiologii Rossiyskoy Akademii Nauk [Poetics and Politics. Almanac of the Russian-French Center of Social Studies and Philosophy of the Institute of Social Sciences of the Russian Academy of Sciences]. Moscow, St. Petersburg, Institut eksperimentalnoy sotsiologii Publ., Aleteya Publ., 1999, pp. 193-226.

6. Bolotnov A.V. Informatsionnoe pole mediynoy yazykovoy lichnosti i ee idiostil [Information Field of a Language Person and its Idiostyle]. Medialingvistika [Media Linguistics], 2015, no. 4 (10), pp. 51-59.

7. Borbot'ko V.G. Printsipy formirovaniya diskursa. Ot psikholingvistiki $k$ lingvosinergetike [The Principles of Discourse Formation. From Psycholinguistics to Linguistic Synergy]. Moscow, Librokom Publ., 2011. 288 p.

8. Borytko A.N. K voprosu o terminologicheskoy yasnosti rechi sportivnogo kommentatora: eksperimentalnoe issledovanie [On Terminological Clarity of Sports Commentator's Speech: Experimental Study]. Izvestiya Volgogradskogo gosudarstvennogo pedagogicheskogo universiteta. Seriya «Filologicheskie nauki», 2012, no. 8 (72), pp. 19-23.

9. Buryakovskaya V.A. Kommunikativnye kharakteristiki massovoy kultury $v$ mediynom diskurse (na materiale russkogo $i$ angliyskogo yazykov) [Communicative Characteristics of Mass Culture in the Media Discourse (on the Material of Russian and English Languages)]. Volgograd, Peremena Publ., 2015. 228 p.

10. Viren G.V. Informatsionnye agentstva $\mathrm{i}$ informatsionnye sayty Interneta: sravnitelnyy kontentanaliz i perspektivnye tendentsii [News Agencies and Information Resources of the Internet: Comparative Content Analysis and Future Trends]. Vestnik Moskovskogo universiteta. Seriya 10, Zhurnalistika, 2009, iss. 3, pp. 74-90.

11. Grishaeva L.I. Kak v mediadiskurse informirovanie stanovitsya manipulirovaniem? [How Can Informing Become Manipulation in the Media 
Discourse?]. Vestnik Moskovskogo gosudarstvennogo lingvisticheskogo universiteta. Yazykoznanie $i$ literaturovedenie. Diskurs kak sotsialnaya deyatelnost: prioritety i perspektivy, 2015, iss. 6 (717), pp. 179-190.

12. Grobitskaya A.M. K voprosu o tematicheskoy stratifikatsii sobytiynogo gazetnogo diskursa [On the Issue of Thematic Stratification of Event Newspaper Discourse]. Vestnik Orlovskogo gosudarstvennogo universiteta. Seriya "Novye gumanitarnye issledovaniya», 2012, no. 7 (27), pp. 324-329.

13. Dobrova V.V., Podlesova O.A. Vidy sobytiy i ikh rolevaya struktura [Types of Events and their Role Structure]. Filologicheskie nauki. Voprosy teorii $i$ praktiki, 2015, no. 8 (50), part III, pp. 76-80.

14. Dobrosklonskaya T.G. Voprosy izucheniya mediatekstov: Opyt issledovaniya sovremennoy angliyskoy mediarechi [The Study of Media Texts. Experience of Studying Modern English Media Speech]. Moscow, KRASAND Publ., 2010. 288 p.

15. Evdokimov V.A. Infoteynment v mass-media: panatseya ot skuki i erzats diskussii [Infotainment in the Media: a Panacea for Boredom and Ersatz Debate]. Nauka o cheloveke. Gumanitarnye issledovaniya, 2010, no. 5, pp. 214-220.

16. Zheltuhina M.R. Mediateksty v sovremennoy massovoy kommunikatsii [Media Texts in Modern Mass Communication]. Vestnik Tsentra mezhdunarodnogo obrazovaniya Moskovskogo gosudarstvennogo universiteta. Filologiya. Kulturologiya. Pedagogika. Metodika, 2013, no. 3, pp. 7-11.

17. Ilyinova E.Yu. K voprosu o konstruirovanii novostnogo soobshcheniya [Focal Points on Constructing News Stories]. Vestnik Volgogradskogo gosudarstvennogo universiteta. Seriya 2, Yazykoznanie [Science Journal of Volgograd State University. Linguistics], 2012, no. 4 (28), pp. 96-102. DOI: http://dx.doi.org/10.15688/jvolsu2.2015.4.11.

18. Ilyinova E.Yu. Kognitivno-diskursivnyy aspekt mediareprezentatsii sobytiya [Cognitive and Discourse aspects of Event Representation in the Media]. Vestnik Moskovskogo gosudarstvennogo lingvisticheskogo universiteta. Seriya «Yazykoznanie». - 2016. - Vyp. 7 (746): Sobytiya v kommunikatsii $i$ kognitsii [Scientific Journal of Moscow State Linguistic University. Linguistics. Iss. 7 (746): Events in Communication and Cognition], 2016, pp. 87-95.

19. Ionova S.V., Matveeva A.S. Spetsifika vremennykh markerov sobytiya $\mathrm{v}$ tekstakh PRdokumenta i zhurnalistskoy publikatsii [Special Features of the Event Marker in PR-Document Texts and Media Publications]. Vestnik Volgogradskogo gosudarstvennogo universiteta. Seriya 2, Yazykoznanie [Science Journal of Volgograd State
University. Linguistics], 2013, no. 2(18), pp. 34-40. DOI: http://dx.doi.org/10.15688/jvolsu2.2013.2.5.

20. Klushina N.I. Intentsionalnaya konfiguratsiya mediynogo prostranstva [International Configuration of Media Space]. Politicheskaya lingvistika, 2013, no. 2 (44), pp. 40-46.

21. Kochetova L.A. Istoricheskaya diskursologiya kak vektor razvitiya teorii diskursa [Historical Discourse Studies in the Theory of Discourse]. Vestnik Moskovskogo gosudarstvennogo lingvisticheskogo universiteta. Seriya «Yazykoznanie i literaturovedenie». - 2015. - Vyp. 6 (717): Diskurs kak sotsialnaya deyatelnost: prioritety $i$ perspektivy [Scientific Journal of Moscow State Linguistic University. Linguistics and Literary Studies. Iss. 6 (717): Discourse as a Social Practice: Priorities and Prospects], 2015,pp. 323-334.

22. Kubryakova E.S. Yazyk $i$ znanie: Na puti polucheniya znaniya o yazyke: Chasti rechi $s$ kognitivnoy tochki zreniya. Rol yazyka v poznanii mira [Language and Knowledge: on the Way to Obtaining Knowledge about the Language. Cognitive Approach to Parts of Speech. The Role of Language in the World Cognition]. Moscow, Yazyki slavyanskoy kultury Publ., 2004. 560 p.

23. Melnikova E.A. Spetsifika mediareprezentatsii realnosti $v$ zhanre novostnoy zametki [The Peculiarities of Reality Mediarepresentation in the Genre of News Story]. Vestnik Volgogradskogo gosudarstvennogo universiteta. Seriya 2, Yazykoznanie [Science Journal of Volgograd State University. Linguistics], 2015, no. 4 (28), pp. 103-107. DOI: http://dx.doi.org/10.15688/jvolsu2.2015.4.12.

24. Bryleva V.A., Volkova O.S., Ionova S.V., Ilinova E.Yu., Kochetova L.A., Safonova O.P. Osnovy lingvisticheskogo monitoringa mediaprostranstva regiona [The Basics of Linguistic Monitoring of the Region Media Space]. Volgograd, Volgogradskoe nauchnoe izd-vo, 2011. $147 \mathrm{p}$.

25. Plotnikova S.N. Diskursivnoe konstruirovanie kak teoreticheskoe ponyatie [Discursive Construction as a Theoretical Concept]. Izvestiya Volgogradskogo gosudarstvennogo pedagogicheskogo universiteta. Seriya "Filologicheskie nauki", 2014, no. 5 (90), pp. $41-46$.

26. Tyrygina V.A. Zhanrovaya stratifikatsiya mass-mediynogo diskursa [Genre Stratification of Mass Media Discourse]. Moscow, Librokom Publ., 2010.320 p.

27. Fedoseeva E.V. Tipy reprezentatsii deystvitelnosti $v$ mediadiskurse (na materiale statey o Rossii v britanskikh i amerikanskikh SMI) [Types of Reality Representation in the Media Discourse (on the Material of Articles about Russia in British and US media)]. Vestnik Irkutskogo gosudarstvennogo lingvisticheskogo universiteta. Seriya "Filologiya", 2014, no. 2, pp. 310-316. 


\section{МАТЕРИАЛЫ И СООБЩЕНИЯ}

28. Bell A. The Language of News Media. Oxford, Blackwell, 1991.227 p.

29. Dominick J.R. The Dynamics of Mass Communication. New York, McGraw-Hill, 1993. 315 p.

30. Elridge J., Kitzinger J., Williams K. The Mass Media Power in Modern Britain. Oxford, Oxford University Press, 1997. 200 p.

31. Hodkinson P. Media, culture and society: an introduction. London, SAGE Publications Ltd, 2013.336p.

32. Ilyinova E.Yu., Volkova O.S. Focal points on constructing news stories. Science Journal of Volgograd State University. Linguistics, 2015, no. 4 (28). pp. 96-102. DOI: http://dx.doi.org/10.15688/jvolsu2.2015.4.11.

\section{SOURCES}

Aberdeen Journal. Available at: http:// britishnewspaperarchive.co.uk/.

Dundee Evening Telegraph. Available at: http:/ /britishnewspaperarchive.co.uk/.

The Manchester Courier. Available at: http:// britishnewspaperarchive.co.uk/.

Western Morning News. Available at: http:// britishnewspaperarchive.co.uk/.

Yorkshire Telegraph and Star (Sheffield Evening Telegraph). Available at: http:// britishnewspaperarchive.co.uk/.

\section{Information About the Author}

Olga S. Volkova, Candidate of Sciences (Philology), Associate Professor, Department of English Philology, Volgograd State University, Prosp. Universitetsky, 100, 400062 Volgograd, Russian Federation, olgavolkova201083@rambler.ru.

\section{Информация об авторе}

Ольга Сергеевна Волкова, кандидат филологических наук, доцент кафедры английской филологии, Волгоградский государственный университет, просп. Университетский, 100, 400062 г. Волгоград, Российская Федерация, olgavolkova201083@rambler.ru, english_philology@volsu.ru. 